\title{
EXPlaining Judicial Populism In Hungary - a LEGAL REALIST APPROACH ${ }^{\mathrm{I}}$ \\ Explicar el populismo judicial en Hungría. \\ Una aproximación desde el el Realismo Social
}

\author{
MÁTYÁs BENCZE ${ }^{2}$ \\ University of Debrecen and Centre for Social Sciences \\ Institute for Legal Studies, Hungary
}

\begin{abstract}
In Hungary, some judges tend to decide cases in a way they think is popular among ordinary people. I call this phenomenon "judicial populism". First, by analysing three cases I argue that the plausible theoretical framework of explanation of populist tendencies in Hungarian adjudication is the American Legal Realism. Then I examine the characteristics and possible explanation of judicial populism and its relation with the political populism.
\end{abstract}

\section{Keywords}

Judicial Populism, Judicial Formalism, Theory of Adjudication, Political Populism, American Legal Realism, Hungarian Judicial Practice.

\section{Resumen}

En Hungría, algunos jueces tienden a decidir los casos de una manera que consideran es popular entre la gente común. Yo llamo a este fenómeno "populismo judicial". En primer lugar, a través de analizar tres casos, sostengo que el marco teórico plausible para explicar las tendencias populistas en la jurisdicción húngara es el Realismo Legal estadounidense. En segundo término, examino las características y la posible explicación del populismo judicial y su relación con el populismo político.

\section{Palabras clave}

Populismo judicial, Formalismo judicial, Teoría de la adjudicación, Populismo político, Realismo jurídico estadounidense, Práctica judicial húngara.

\section{Introduction}

In Hungary, some judges tend to decide cases in a way they think is popular among ordinary people. I call this phenomenon "judicial populism". ${ }^{3}$ I argue in this paper that judicial populism cannot be explained correctly — and cannot even be detected — by interpreting and evaluating judgments with utmost good faith.

\footnotetext{
${ }^{1}$ This publication is part of the DEMOS project and has received funding from the European Union's Horizon 2020 research and innovation programme under grant agreement No 822590. Any dissemination of results here presented reflects only the authors' view. The Agency is not responsible for any use that may be made of the information it contains. I am grateful to my reviewers for their valuable comments.

${ }^{2}$ Mátyás Bencze, professor of law, University of Debrecen, research fellow, Centre for Social Science, Institute for Legal Studies. E-mail: bencze.matyas@tk.mta.hu ORCID: https://orcid.org/0000-0003-3234-0440

${ }^{3}$ Another group within the judiciary remains more loyal to the law, and sticks to the principles of established judicial practice, even if that makes them unpopular to the point where they have to face heavy criticism or even threats from politicians and journalists. But this is another story I will analyse in a different paper.
} 
While the version of American Legal Realism, which is commonly characterized as "rulescepticism" (Frank, 1949), has been under permanent attack (Hart, 2012) and sometimes treated with sarcasm (Kozinski, 1993) its explanatory force has proved surprisingly strong in certain fields of adjudication (Danziger et al., 2011). The most important observation of Legal Realists is that the law (whatever we mean by this term) is flexible enough to support —on repeated occasions - legal decisions which even oppose each other (Frank, 1963). By using a wide scale of legal arguments judges can hide the extra-legal factors which influence their decision in reality. That is why maintaining the coherence of law (and judicial decisions) is not as compelling a requirement for judges as doctrinal legal scholars and many legal theorists consider it to be. That is why the always distrustful Legal Realism may be the most appropriate theoretical framework for investigating a new development in Hungarian judicial practice.

First, I describe three recent cases which are examples of this development; then, I present the possible explanations of the judicial decisions and argue that the legal realist approach is useful for revealing some extra-legal factors behind Hungarian judicial practice. Finally, I outline the sociological characteristics of judicial populism.

\section{Three judicial decisions}

In the last few years the number of controversial judicial decisions from all branches of adjudication has been increasing, and they share some common distinctive features. I will summarize three of them (all the three are criminal cases as I have expertise only in this field of law); then I will highlight the common features of these judgments and try to seek a plausible explanation for them.

\subsection{A millionaire shall be held in detention}

In 2013 a striking decision was issued. A Slovakian woman, mother of two children, killed four people in a car accident when driving recklessly on a Hungarian motorway. It is important to know that the perpetrator is a millionaire who has been often seen on the front pages of Slovakian tabloids. The Hungarian court of first instance sent her to prison for six years, at the same time, however, releasing her from detention and ordering her house arrest until the final decision of the appellate court was delivered. The decision on house arrest provoked a huge public outcry in a large section of the public that believes rich people always get special treatment. They were convinced that the court had made an exemption when, instead of keeping the millionaire in jail, let her return to her own home so that she could go on living her luxurious life. ${ }^{4}$ Nine days later the appellate court changed the decision on the house arrest and re-ordered the post-charge detention, explaining its decision with the "flight risk" of the defendant. The appellate court presented no evidence as regards a planned flight attempt. It simply stated that she was rich enough to organize her own escape, even from a house arrest (Budapest Környéki Törvényszék, 2013). In 2014 the appeal court increased her prison sentence to 9 years. One of the reasons for the aggravation was that the accident caused huge public outcry. ${ }^{5}$

\subsection{Red mud disaster}

In 2010 an industrial accident at a caustic waste reservoir chain occurred at an alumina factory in the western part of Hungary. ${ }^{6}$ As a consequence of the disaster toxic "red mud" killed 10

\footnotetext{
${ }^{4}$ For the media reaction see Hungarian Specturm (2013).

${ }^{5}$ See, Janecskó (2014) and Daily News Hungary (2014).

${ }^{6}$ See, Wikipedia (2010).
} 
people. In 2016 a judge cleared all the 15 defendants who were employees at the alumina company (from the CEO of the company to the warden of the reservoir). The decision was considered outrageous by many people. ${ }^{7}$ The appeal court quashed the ruling in February 2017 and ordered a retrial. The reason was that the court of first instance did not provide sufficient reasoning for the judgement. In the repeated procedure ordered by the appellate court the trial court found guilty 10 defendants of the $15 .{ }^{8}$

\subsection{A fast and furious camerawoman'}

In October 2018, the Curia (Supreme Court of Hungary) acquitted a journalist (a camerawoman) from charges of violent attack against refugees on the Hungarian-Serbian border in 2015. The Curia, by reversing the judgments of lower courts, found that the journalist did not commit the crime of public nuisance when, without any lawful reason, she tripped and kicked refugees fleeing the police on the border, since the act of the journalist was not blatantly antisocial with regard to the public peace, which had been already disturbed by the fleeing migrants themselves. ${ }^{10}$

It must be added that the three cases summarized above are just a few examples from a pool of similar cases. We can find an ever-increasing number of judgments with the same characteristics (Bencze, 2014).

\section{Legal evaluation of the decisions}

As it is obvious, in the first case the mere facts of being rich and a foreign citizen cannot be the basis for detention without other circumstances that present the risk of escaping sufficiently serious. As for the final judgment, the harshness of the sentence is far above the average length of prison sentences in similar cases. In the table below I have collected the decisions that represent the judicial practice.

\begin{tabular}{|c|c|c|c|}
\hline CASE IDENTIFIER & $\begin{array}{l}\text { NUMBER OF PEOPLE } \\
\text { KILLED IN THE ACCIDENT }\end{array}$ & OTHER CIRCUMSTANCES & Sentence \\
\hline FBK 1993/21. & No data & No data & 6 years \\
\hline BH 1978.3.107 & 4 & $\begin{array}{l}16 \text { other people injured } \\
\text { No criminal record }\end{array}$ & 7 years \\
\hline Bfv.317/2007/5 & 3 & $\begin{array}{l}5 \text { other people injured } \\
\text { Has a criminal record }\end{array}$ & 7 years \\
\hline EH 2003.932 & No data & No data & 7.5 years \\
\hline Kiskunfélegyháza & 4 & Has a criminal record & 8 years \\
\hline Rezesova & 4 & $\begin{array}{l}\text { No criminal record, } \\
2 \text { children }\end{array}$ & 9 years \\
\hline
\end{tabular}

Figure 1

\footnotetext{
${ }^{7}$ See, Mandiner (2016).

${ }^{8}$ See, Budapest Business Journal (2019).

${ }^{9}$ This case is from a manuscript written by the author and Ágnes Kovács titled "Judicial independence and models of court administration".

${ }^{10}$ Currently, only the press release is available is: Kúria (2018).
} 
In the second case the appeal court used a "jolly joker" argument, namely the argument of "insufficient reasoning". According to the Hungarian Criminal Procedure Act the lack of sufficient reasoning qualifies as a serious violation of the fair trial principle and thus can be the basis for quashing a judgement. Nonetheless, the law does not specify the required minimal extent of sufficiency, so courts of appeal can interpret this provision of the code very flexibly if they do not agree with the verdict of the trial court, and they do not have any other legal opportunity to overturn it. ${ }^{11}$ It is also worth mentioning that one retired senior judge wrote a book on this case and she characterized the trial judge as one of the most competent judges she had ever seen. ${ }^{12}$

In the third case, the Curia delivered a decision and argumentation that greatly deviated from the coherent judicial practice, which existed in public nuisance cases. It held that the flight of the refugees had already caused disturbance, and thus the behaviour of the camerawoman could have not caused it (causing turmoil is one of the legal criteria of guilt in public nuisance cases). ${ }^{13}$ This reasoning implies the absurd conclusion that everybody can kick another person without facing charges in a scene of turmoil.

\section{Possible explanations}

From a legal formalist point of view, which requires from the judge a textualist approach combined with the correct application of legal concepts and legal institutions, the possible explanation might be that the judgements presented in every case are all the result of accidental judicial miscarriages that occur in every legal system. However, these judicial miscarriages, just like cases of medical mistreatment, stemmed from negligence or ignorance, and it is hard to believe that in all three cases — where experienced senior judges of higher courts made the decisions in a judicial panel_ negligence or ignorance were the main reasons such controversial judgments were delivered. On the other hand, as we will see later, if we were simply dealing with judicial miscarriages, we would not be able to find a suspicious common tendency in all the judgments examined.

Another possible perspective is the Dworkinian approach (Dworkin, 1996). It may be that the judges in those three cases have a strong conservative-communitarian political view. At first glance, this might explain the decisions, as in all three cases judges thought that the interests of the Hungarian political community had to prevail over other legal principles such as proportionality, the right to a fair trial and equality. It is easy, however, to realize that xenophobia (in the first and the third cases) is not a moral principle, even if the majority of Hungarian citizens share this attitude. As for the second case (the red mud disaster) solidarity with victims may be the sign of communitarian attitude, but prejudice towards a company which represents "Big Money" is also a plausible explanation.

Besides this we must bear in mind that cases were decided in such a way that pleases the man or woman in the street. This mentality is not an attribute of conservative political thinking at all. Furthermore, we conducted an on-line survey amongst Hungarian judges in order to determine their judicial attitudes and our findings showed that there is no conservative majority within the judiciary (Bencze, 2013). To sum up the analysed decisions cannot be sufficiently explained either from a formalist or from a Dworkinian point of view. Following from that, another explanation should be elaborated. The starting point is that there are some common features in all the three cases.

\footnotetext{
${ }^{11}$ See, Kúria Büntető Kollégium (2012).

${ }^{12}$ See the video of the scholarly discussion on the first instance judgement in: Youtube (2017).

${ }^{13}$ See, EH 2019.03.B5
} 
The first is that judges, although used legal arguments, did not provide their judgements with sufficient reasoning. Whether a judge engages with rule-based decision-making or with the Dworkinian model, her first-order obligation is to take all relevant legal reasons into consideration. Then, the judge has to present a transparent, coherent and convincing explanation for why she emphasized one of these reasons and not others in the decision-making process. Judges in all three cases significantly limited the number of adequate legal reasons, that is, they did not take their professional obligations seriously.

Secondly, the cases received — although to varying extents — nation-wide publicity. Judges knew that the wider public would be informed of their decisions. Besides, pressure on courts exercised by politicians was clearly detectable in all the three cases. In the Rezesova case, one prominent member of the governing party (Fidesz) shortly after the judgement of the trial court took along a cameraman and delivered a short message in front of Rezesova's residence, which he placed on his Facebook site. He expressed his disgust and, in the name of the Fidesz parliamentary faction, called on the parliamentary committee dealing with legal matters and on the minister of justice to investigate the outrageous decision that the defendant could spend her time between the two trials in the comfort of her home. ${ }^{14}$ In the second case, when the ruling of the first instance court was issued, one of the leaders of Fidesz publicly denounced the judgment as outrageous and initiated a parliamentary debate about the administration of justice. He stressed that the ruling party respected the "liberal" standard of judicial independence but democratic values such as transparency and accountability should have been enforced, as well. ${ }^{15}$ In the case of the camerawoman there was no direct pressure, but it is important to know that the judgment obviously fits into the hostile approach of the government towards migrants. ${ }^{16}$

Following from this, it is safe to say that the judicial decisions in the three cases were influenced by extra-legal factors in a hidden way. By "hidden way", I mean that at the textual level of the judgments one cannot find a direct reference to extra-legal factors, they use only professional, legal-doctrinal language. This is why Legal Realism can be an adequate theoretical framework for a more detailed examination of the tendency presented here. Legal realism is a theory which emphasizes the impact of extra-legal factors on judicial practice and, at the same time, incorporates the flexibility thesis: the language of the law is flexible enough to maintain the appearance of the legal-professional character of the decision. Legal realism also paves the way for a sociological explanation of the judicial practice.

My hypothesis is that the explanation for the judgements presented comes from an attitudinal extra-legal factor. I call this type extra-legal factor "judicial populism". Before examining the plausibility of my explanation, I must clarify what I mean by the term "judicial populism".

\section{What does populism mean in a judicial context?}

The term populism in the field of legal scholarship generally refers to the behaviour of the legislator. Political populism is a strategy to gain more political power by pandering to public sentiment, and professing to protect the interests of "ordinary people" against the "elite" (Canovan, 1981). One of the obvious examples is what David Garland described as "penal populism" in the field of criminal legislation (Garland, 2001).

It is my belief that populism plays a different role in judicial behaviour. Ordinary judges very rarely aspire to governmental power. That is why in the field of judicial practice

\footnotetext{
${ }^{14}$ Hungarian Spectrum (2013).

${ }^{15}$ Magyar Nemzet (2016).

${ }^{16}$ For an overview, see http://abouthungary.hu/illegal-immigration/
} 
populism, at least in the form I examine it, is not a means to gain more political power. Judicial populism is rooted in a "drifting with the tide" mentality. Populist judges do not tend to confront the perceived opinion of the vast majority of people or powerful social groups, groups which, like many ordinary people, usually do not have too high an estimation of the value of traditional legal reasons in resolving sensitive legal disputes. This is the reason why I find the category of "populism" appropriate to conceptualize the phenomenon outlined here. Judicial populism, like political populism, systematically devalues the professional approach to solving problems in favour of making a decision that is popular amongst ordinary people. The pattern of the behaviour of actors is the same in both cases: they present their acts as being in the service of ordinary people and in doing so they distinguish themselves from the "elite group" (politicians, lawyers) to whom they are commonly considered to belong. This may result in a decline in expert authority in both forms of populism (Zimring, 1996).

As part of the conceptual clarification of judicial populism it may be useful to mention a caveat here. Judicial populism is not the same as popularizing judicial decisions (explaining and communicating the judgements issued in a clear and understandable language for ordinary citizens). As we could see, the decisions discussed above were populist in their result, and not in their language of argumentation.

The way I have clarified the concept of judicial populism in the last few paragraphs may make it quite obvious that I treat the phenomenon examined as a certain type of behaviour of judges. On one hand, this approach implies that populism may have an impact on the motivation of a judge when deciding a case.

There might be two main reasons for a judge to follow the populist adjudicative method. When a judge truly believes that (s)he has to take into consideration the interests and opinion of ordinary people, we can refer to this as "honest populism". On the other hand, populism may also serve as a kind of judicial strategy, where judges follow a purpose by applying this strategy that can be clearly distinguished from the purpose of satisfying public needs and sentiments. "Strategic populism", for example, may serve a "shield" function that can help judges, under uncertain political circumstances, to secure their institutional position through the external support of the public sphere.

In order to examine the strategic use of populism we need to turn to public choice theory. In this case we have to see courts as players in the arena of governmental politics, who tend to enforce their institutional interests by applying various strategies. I find it possible that Hungarian courts use a populist strategy in some cases as a means of fulfilling their institutional purposes. Nonetheless, we do not have enough empirical data that could justify or falsify the presence of a strategic use of populist adjudication in Hungary. That is why I scrutinize judicial populism as a form of judicial approach to legal problems and I try to discover the circumstances which have facilitated the emergence of populism amongst Hungarian judges.

What are the main attributes of this judicial approach? In order to answer this question it would be useful to compare populism with another judicial approach also driven by extra-legal considerations, namely with pragmatism.

There is a similarity between the two approaches: both of them focus on the social impact of the decision and do not care much about its legal correctness. Nonetheless, pragmatist judges consider more important to adequately reflect the social needs behind the law. Several representatives of the pragmatist approach have a clear concept of the social function of law that adjudication should serve (Posner, 1996). These versions of judicial 
decision-making can be called "reflective" pragmatism, since we may discover a more or less coherent ideology which drives them in a series of judgments.

As for judicial populism, one of its essential features is that judges deciding certain cases feel bound to the views and sentiments of the "ordinary man or woman". This serves as a solid orientation point for a populist judge in delivering a judgment. It would, however, be misleading if we characterised populism as a kind of reflective pragmatist approach. The populist approach is certainly pragmatist in a sense. For a populist judge the practical consequence of a decision does matter, rather than the inner coherency of law or the justification of moral principles. However, reflective pragmatists see judicial power as a means to achieve a certain social aim and they are sensitive to the long-term consequences of the judgement. On the contrary, a populist judge does not reflect on the deeper social consequences of his or her decision. What matters for a populist judge is the immediate reaction from the media and "ordinary people" to her decision.

From this short comparison we can conclude that if a judge deliberately breaches the standards of proper legal reasoning in order to satisfy the presumed expectation of "ordinary people", we may talk about judicial populism.

\section{The sociological background of judicial populism}

Adjudication is a fundamentally and profoundly political activity since judicial decisions determine the life of citizens in the same way as legislative acts do. The difference between judicial and legislative decision-making can be found in their scope (any citizen or the involved parties) and not in their character. Courts and parliaments are equally entitled to impose duties on citizens on the ground that they have the authority (legitimate power) to do so (Dworkin, 1980). This authority is deeply rooted in the political settings of the society in question. Different societies therefore may have different grounds of authority (divine power, charisma of the leader, democratic legitimacy etc.). In the vast majority of modern Western societies the authority of courts, as in the case of legislation, can be derived from the agreement of the members of the whole political community ("people"). That is why courts are bound to the circumstances of politics, and their activities cannot be understood as a purely professional activity. Therefore, it is not a coincidence that populism, as it is in the case of politics, is one of the possible answers deriving from the expectations of the political community toward the courts. ${ }^{17}$

Beside this similarity between politics and adjudication there are two other tendencies that may facilitate the world-wide spread of judicial populism, namely the politicisation and mediatisation of adjudication (Hack, 2014). With increasing frequency over the past three decades sensitive political cases have been brought before courts. Moreover, in some cases - mostly criminal ones - court judgments have themselves acquired political significance.

Since the early nineties the media has also paid increasing attention to court trials, and court trials have been more and more frequently broadcasted. Some interesting cases are watched by tens of millions of viewers on a daily basis in the form of a TV show. The presence of journalists and TV cameras may have an impact on the behaviour of judges. It has been already detected that in some countries court decision are sometimes influenced by popular sentiment. ${ }^{18}$

\footnotetext{
${ }^{17}$ Lon Fuller has already described judicial populism as one of the argumentative strategies of judges in his famous parable of the Speluncean Explorers. It is Justice Handy who represents the populist view (Fuller, 1949).

${ }^{18}$ For example, in India: "Far too many in the Indian judicial system are reacting and responding to public sentiment and pressure with an eye on television cameras rather with their eyes blindfolded like Lady Justice. Judicial populism has become a disease, an affliction that runs the risk of creating institutional paralysis" (Business Standard, 2013).
} 
In Hungary these tendencies have also occurred over the past fifteen years, creating the preconditions for the emergence of judicial populism. The three cases I mentioned above indicate that populism is an existing judicial approach amongst Hungarian judges. Being aware of the fact that some populist judicial decisions can be delivered in almost every period and every legal system, ${ }^{19}$ the question is therefore why it might be worthwhile to examine Hungarian judicial practice from this perspective.

Research has shown that this phenomenon in Hungary is part of a general tendency that can also be detected in some of the CEE countries. In these legal systems we are confronted with a greater intensity of populist judgments than in Western countries. ${ }^{20}$

Over the past few years several surveys have revealed that Hungarian courts have adopted an explicitly majority-protective legal position in hate crimes cases (Jovánovics et al., 2013; Bencze 2014), and Hungarian justice has more frequently found Romany people guilty in one of the hate crimes (violence against a member of a community) than non-Romany ones (Jovánovics, 2013). Paradoxically, the objective of the legislation, which introduced hate crime into the Penal Code, was to protect vulnerable minorities. ${ }^{21}$ In the field of sentencing a significant bias can also be detected, especially in murder cases. It seems that many judges tend to impose severe sentences on perpetrators coming from ethnic minorities. On the other hand, judges are usually more lenient when it comes to crimes committed against ethnic minorities (Ivány, 2012).

It is important to mention two facts here. On one hand, hate crimes committed against non-Romany people almost always receive nation-wide publicity; on the other hand, a survey conducted by the Hungarian Helsinki Committee referred to above did not find any difference in sentencing between Romany and non-Romany perpetrators in robbery cases which did not trigger a "threshold stimulus" for the national media. Taking into consideration that a promajority mentality is one of the characteristics of populism in CEE countries (Smilov, 2010), these two facts seem to support the hypothesis that the populist approach and not racism is responsible for numerous judicial miscarriages in Hungary.

Beside criminal cases, we can find the trace of judicial populism in other branches of adjudication, as well. If we scrutinize the published civil or administrative court verdicts from the past 15 years — with one exception - we cannot find cases where any fundamental rights would have overridden the right to religious freedom or religious sentiments in cases where one of the parties was the Catholic Church itself. It is an important feature of all these cases that the legal correctness of the judgements was highly controversial (Bencze et al., 2015). According to the results of the last two censuses, it is obvious that the majority of Hungarian society identifies itself as Roman Catholic. A plausible explanation of the legally arguable decisions therefore is the pro-majoritarian populism of the courts.

\section{Judicial formalism and judicial populism}

My analysis may surprise those who have studied the extensive literature of judicial styles in CEE countries. According to the predominant view, the problem with judiciaries in these countries is quite the opposite to my findings: judges generally follow a formalist adjudicative style that often leads to absurd decisions (Fogelkou, 2002; Kühn, 2004; Galligan et al., 2005; Schwartz, 2000; Falkner et al., 2008).

\footnotetext{
${ }^{19}$ For example, see IRA-related miscarriages of justice in the United Kingdom: The Guardian (2009).

${ }^{20}$ Smilov, after having examined the tendency of adjudication in Bulgaria and other orthodox Eastern European countries, comes to a similar conclusion (Smilov, 2010).

${ }^{21}$ The amendments can be found in: http://www.parlament.hu/iromany/fulltext/00548txt.htm
} 
Why is the situation, at least partly, different in Hungary and some other CEE countries? First, we have to clarify the concept of judicial formalism. Formalism is often characterized as the "most-locally-applicable-rule" approach in legal decision-making (Schauer, 1991). This means that the practitioner tries to solve a given legal problem by relying exclusively on the text of the law, accepted legal doctrines and the traditional interpretive methods, without taking into consideration the wider social and legal context of the case. This model represents a judicial attitude to remaining loyal to traditional legal reasons, as they serve the idea of the rule of law the best. This attitude often lies behind the above-mentioned formalist model of adjudication.

Although this description of formalism may explain a certain type of the possible judicial approaches to "easy" or "routine" cases satisfactorily, it is certainly misleading when it comes to "hard cases" in which the law is uncertain. It is obvious that in deciding a difficult case a judge cannot bind herself to the text of the rule, since the applicability of the "most locally rule" becomes itself questionable in such cases. In this situation judges necessarily have to seek a ground for resolving the legal problem in front of them other than finding traditional legal reasons. Nonetheless, it does make sense to speak about the formalistic adjudicative approach in cases where a judge has to deal with a difficult legal problem. If a judge does not depart from traditional legal arguments in providing reasons for the judgment even in difficult cases, we can also label her method formalistic. In this case the judge's decision cannot be deduced from the traditional legal arguments that she presents in the opinion, even though she refers only to those arguments.

On the basis of distinguishing between these two senses of the term under examination, one can see that on one hand, formalism is a certain judicial attitude ("most-locally-applicablerule" approach), and on the other, a kind of judicial strategy (the judge presenting the decision as a logical deduction from traditional legal arguments). One can also easily realize that strategic formalism can be used not only in genuine hard cases but in any other cases where the judge intends to diverge from the results that would otherwise be required from a trained judge. Under these circumstances formalism may function as a cover for the judge's hidden agenda.

Strategic formalism, which is quite widespread amongst Hungarian judges (Bencze, 2011), therefore facilitates the emergence of judicial populism. Judgments driven by populism cannot be criticised on the basis of relying on illegitimate reasons, because the judgment, seemingly, is supported by appropriate legal arguments. ${ }^{22}$ This method, furthermore, prevents parties and the public audience from understanding the real considerations driving the judge in the decision-making process. Judicial populism therefore presupposes the strategic use of traditional legal arguments, because a judge — at least in the Continental legal culturescannot refer openly to public sentiment. ${ }^{23}$

\footnotetext{
${ }^{22}$ The "King" of formalistic arguments is probably the often used reference to the "court's own legal standpoint" — without any further clarification (Bencze, 2011).

${ }^{23}$ Logically, the next step would be to explore the circumstances which could cause the emergence of strategic formalism. Such an examination would lead far from the original subject of this paper. Nonetheless, two factors can be mentioned here: 1) the lack of any institutionalized quality-control mechanism against judicial reasoning (for example, we can hardly detect any real impact of scholarly criticism on Hungarian adjudication); 2) in Hungary the quality of statutory drafts counts as a serious problem. Drafters have the tendency to formulate 'the Legislator's Will' in vague and uncertain terms (using the language of abstract declarations) which makes the adjudication unpredictable and somehow uncontrollable. This has led directly to the use of the oversimplified, "one-size-fits-all" type of argument which is spreading among judges and makes it easier to provide legally flawed populist decisions with token reasoning (Bencze, 2018).
} 


\section{The Hungarian flavour of judicial populism}

Apart from the above-mentioned general tendency towards the mediatisation and politicisation of adjudication, some factors can also be identified that have a strengthening effect on the spreading of judicial populism in Hungary.

First of all, we must mention that political populism in Hungary has become stronger over the last few years. There are many unambiguous examples of the application of this political strategy. Criminal legislation in the past 10 years has followed a "classic" populist agenda (Gönczöl, 2013; Tóth, 2012; Fleck, 2014). One of the first moves the new government took in 2010 was to enact the notorious "three strikes" provision in the Penal Code. ${ }^{24}$ A parliamentary majority then implemented an American style "lawful defense" making legal the murder of a trespasser under certain circumstances. ${ }^{25}$ Following this, the Hungarian government declared it would uphold the literal "life" imprisonment against the decision of the European Court of Human Rights which holds that it is an inhuman and degrading punishment. ${ }^{26}$ Recently, Hungarian legislation has criminalized some forms of help for asylum seekers and homelessness. ${ }^{27}$

This may generate a similar attitude on the part of the judiciary (those who have an inclination to be popular), implying that a good judge serves the people rather than being a black-letter lawyer. As the reigning political party is doing the same thing in the field of politics and legislation (e.g. "getting tough on crime") many judges may feel her populism justified. They may think that they can only win if they follow governmental strategy.

In some cases, courts have had to deal with manifest political pressure when making certain decisions (as we could see all the three cases discussed above) ${ }^{28}$ Under such pressure many judges may sacrifice their professional conviction and independence for swifter progress in their personal career.

Secondly, the value-system of Hungarian society is (according to WVS $5^{\text {th }}$ wave, [Keller, 2009] $)^{29}$ probably closer to the value-system of the Orthodox-Christian Eastern European countries than to other non-orthodox post-socialist nations. This indicates a relatively closed-minded society with a higher level of intolerance, the devaluation of human rights and liberty, the weakness of civil society and a general distrust of institutions. That is why populist judicial acts that typically hit vulnerable groups and individuals are welcomed by the majority of society. This can be the reason why judicial populism has become a serious threat to the rule of law in Hungary while it has only remained an isolated phenomenon in the Czech Republic and Poland (Smilov, 2010; Vig, 2014).

\footnotetext{
${ }^{24}$ Art. 4, Act LVII of 2010

${ }^{25}$ Art. 22, Act C of 2012

${ }^{26}$ The Case of László Magyar v. Hungary. For governmental reaction, see http://nol.hu/belfold/trocsanyi-marad-a-tenylegeseletfogytiglan-1466965

${ }^{27}$ The Guardian (2018) and Palfi and Tidey (2018).

${ }^{28}$ We can also find another case of open governmental pressure on courts. Following a judgement of one of the Regional Court of Appeals in which the court reduced the length of time of imprisonment of three Romany defendants who were all involved in the murder of a very popular athlete, the Minister of Justice and Public Administration sent a letter to the President of Hungarian Supreme Court. In this letter, which he wrote before the final judgment of the Supreme Court, he expressed his worries regarding the over-lenient sentencing practice of the courts, http://m.cdn.blog.hu/at/ataszjelenti/file/ Dr.\%20Dar\%C3\%A1k\%20P\%C3\%A9ter\%20\%C3\%BArnak\%20lev\%C3\%A9l.pdf.

${ }^{29}$ See also http://www.worldvaluessurvey.org/
} 


\section{Evaluating judicial populism}

One cannot say that populism is an inherently negative phenomenon that we should expel from all spheres of public life. I would characterize it as a very dangerous tool, even though we need to resort to it sometimes. Taking the case of politics, there are very important messages and complex long-run political enterprises that do not have any impact on the wider public sphere unless we massively simplify them. That is why I have gathered some arguments pro and contra judicial populism.

First, we all know that the established judicial practice needs external challenges from time to time in order to be able to renew itself. Adjudication has to reflect social needs, and the requirements of the "Zeitgeist" also have to be followed somehow (in the sense the US Supreme Court did in the famous Brown decision). On the other hand, the populist approach oversimplifies legal-doctrinal questions and makes the law primitive and incapable of responding to the needs of a complex society.

Secondly, populism builds the image of the "Good court", and in this way it generates public trust in the justice system. However, at the same time it violates the principles of the rule of law and equality. Thus it may have a detrimental effect on the justice system in the long run.

Thirdly, lay justice is an organic part of justice systems almost everywhere in the world. The populist approach may substitute the merely formal lay participation (which is the case in Hungary, [Badó et al., 2007]) by embedding lay attitudes in the mentalities of professional judges. Nonetheless, it is the first order duty of professional judges to enforce the internal values of the law, rather than ignore them. That is why we cannot find "pure" lay justice systems anywhere in the modern world.

Besides these reasons, there are two general objections against the populist judicial approach. First, popular wishes sometimes simply do not deserve to be fulfilled; the question of what qualifies as right or wrong in a moral sense cannot be answered by referring to the majority's opinion (the moral-philosophical argument). Second, the "will of the people", or the "sentiment of the public", etc. are very confusing ideas. It is very difficult to obtain wellgrounded empirical data on them (the sociological argument).

In my opinion, these arguments show us that ordinary people may have their say in justice administration but not in a crude and direct manner. The legislator and professional judges should filter the 'will of the people'. Actually, these institutions are designed to tackle this task.

\section{Questions, instead of a conclusion}

I must emphasize that judicial populism is not the prevailing attitude amongst Hungarian judges; it is an existing phenomenon, though, which should be taken seriously. The very category of populism might need some further refining. It is possible that the category of "social conformism" better describes the phenomenon examined.

Explaining and understanding this phenomenon also requires further legalsociological research. The theoretical questions arising from the examination of judicial populism are as follows:

The first question is whether judicial populism is a precursor of an emerging authoritarian regime, given that a populist judiciary is no longer independent, and can easily be influenced by powerful political actors.

Secondly, how can we reconcile the Internet-based and increasing democratization of the justice system and the need for a complex legal system in a heterogeneous society? The decline of expert authority is a threat to complex social systems such as the law. 
And thirdly, what kind of social sensitivity would be desirable from judges? How can we distinguish between legitimate social sensitivity and illegitimate deference to the mood of the populace?

\section{Bibliografic References}

Badó, A. and Bencze, M. (2007). Reforming the Hungarian Lay Justice System. In P. Cserne, I. H. Szilágyi, M. Könczöl, M. Paksy and Sz. Tattay (eds.). Theatrum Legale Mundi. Symbola Cs. Varga Oblata (pp. 1-13.). Budapest: Societas Sancti Stephani.

Bencze, $\mathrm{M}$ and Drótos, $\mathrm{R}$ (2015). A társadalmi tekintély szerepe az ítélkezésben — tradicionális keresztény egyházak jogai és érdekei a magyar bíróságok előtt [The Role of The Social Authority in the Adjudication - the Rights and Interests of the Traditional Christian Church before Hungarian Courts]. Állam- és Jogtudomány, 56 (3), 3-28.

Bencze, M (2014). Gyülelet büncselekmények és “ítélkezési populizmus” [Hate crimes and 'Judicial Populism']. Fundamentum, 18 (1-2), 129-139.

- (2011). Elvek és gyakorlatok [Principles and Practices]. Budapest: Gondolat.

- (2013). Az alapjogok bíróság előtti érvényesülésének szociológiai háttere. [Legal Background of Enforcement of Fundamental Rights]. In B. Somody (ed.). Alapjogi biráskodás - alapjogok az itélkezésben, (pp. 102-105). Budapest: L'Harmattan.

- (2018). Obstacles and Opportunities - Measuring the Quality of Judicial Reasoning. In Bencze, M. Bencze and N. Gar Yein Ng (eds). How to Measure the Quality of Judicial Reasoning (pp. 87-101). New York: Springer.

Canovan, M. (1981). Populism. New York and London: Harcourt Brace Jovanovich.

Danziger, S, Levav, J, and Avnaim-Pessoa, L (2011). Extraneous factors in judicial decisions. Proceedings of the National Academy of Sciences of the United States of America, 108 (17), 6889-6892.

Dworkin, R (1996). The Moral Reading of the Constitution. The New York Review of Books. http://www.nybooks.com/articles/archives/1996/mar/21/the-moral-reading-ofthe-constitution/?page $=1$.

- (1980). Political Judges and the Rule of Law, Maccabaean lectures in jurisprudence. British Academy.

Falkner, G and Treib, O (2008). Three Worlds of Compliance or Four? The EU-15 Compared to New Member States. Journal of Common Market Studies, 46 (2), 293-313.

Fleck, Z. (2014). Civilizációs válság és büntető populizmus [Civilizatory Crisis and Penal Populism]. In A. Borbíró, É. Inzelt, K. Kerezsi, M Lévay and L. Podoletz (eds.). A büntetöhatalom korlátainak megtartása: a büntetés mint végsö eszköz (pp. 149-161). Budapest: ELTE Eötvös Kiadó.

Fogelkou, A (2002). East European Legal Thinking. RGSL Working Papers. https://www.rgsl. edu.lv/uploads/working-papers-list/26/rwp4fogelklou.pdf

Frank, J. (1963). Law and the modern mind. New York: Anchor Books.

Fuller, L (1949). The Case of the Speluncean Explorers. Harvard Law Review, 62 (4), 1851-1871.

Galligan, D. and Matczak, M. (2005). Strategies ofJudicial Review, ExercisingJudicial Discretion in Administrative Cases Involving Business Entities. Warsaw: Ernst \& Young.

Garland, D. (2001). The culture of control: Crime and social order in contemporary society, Chicago: University of Chicago Press. 
Gönczöl, K (2013). A "büntető populizmus" [Penal Populism]. Élet és Irodalom. http:// angelusz.elte.hu/sites/default/files/B\%C3\%BCntet\%C5\%91pop.pdf

Hack, P (2014). Péter Hack’s contribution to the conference "Az igazságügyi adatkezelésről és tájékoztatásról szóló törvény koncepciója”. http://www.birosag.hu/sites/default/ files/jegyzet_0207_oszesitett_javitott_ta_0.pdf.

Hart, H. L. A. (2012). The Concept of Law. Oxford: Oxford University Press.

Ivány, B (2012). Minősíthetetlen szigorúság. szuveren.hu. http://www.szuveren.hu/jog/ minosithetetlen-szigorusag

Jovánovics, E (2013). A tárgyalótermek fantomja: a rasszista cigány. http://ataszjelenti.blog. hu/2013/02/20/a_targyalotermek_fantomja_a_rasszista_cigany.

Jovánovics, E and Pap, AL (2013). Kollektív bünösség a 21. század Magyarországán: magyarellenesség vádja cigányokkal szemben két emblematikus perben. Fundamentum, 17 (4), 153-157.

Keller, T. (2009). Magyarország helye a világ értéktérképén Elemzés a World Value Survey kutatás 5. hulláma alapján [The Place of Hungary in the World Map on the Basis of the $5^{\text {th }}$ wave of the World Value Survey]. Budapest: Tárki.

Kúria Büntető Kollégium (2012). A bíróságok hatályon kívül helyezési gyakorlatának elemzése Büntető ügyek 2012. Összefoglaló vélemény. Kuria Birosag. https://kuriabirosag.hu/sites/default/files/joggyak/osszefoglalo_velemeny_2012iimod2_2.pdf

Kozinski, A (1993). What I ate for breakfast and other mysteries of judicial decision making. Loyola LA L Rev, 26 (4), 993-999.

Kühn, Z (2004). Worlds Apart. Western and Central European Judicial Culture at the Onset of the European Enlargement. American Journal of Comparative Law, 52 (3), 531 568.

Posner, RA (1996). Pragmatic Adjudication. Cardozo Law Review, 18 (1), 1-20.

Schauer, F. (1991). Playing by the rules. A philosophical examination of rule-based decisionmaking in law and in life. Oxford: Clarendon Press.

Schwartz, B. (2000). The struggle for Constitutional Justice in Post-Communist Europe. Chicago and London: University of Chicago Press.

Smilov, D. (2010). The Rule of Law and the Rise of Populism: A Case Study of Post-Accession Bulgaria. In K. Topidi and A. H. E. Morawa (eds.). Constitutional Evolution in Central and Eastern Europe: Expansion and Integration in the EU (pp. 270-272). Aldershot: Ashgate.

Tóth, M (2012). Egy büntetőjogász gondolatai a "vox populi” oldalvizén [A Criminal Law Scholar's Thoughts on "Vox Populi"]. ujbtk.hu. http://ujbtk.hu/dr-toth-mihalyegy-buntetojogasz-gondolatai-a-vox-populi-oldalvizen/

Vig, D. (2014). Vigyázó szemetek keletre (is) vessétek! - Büntető populizmus és tömeges bebörtönzés Grúziában [Penal Populism and mass incarceration in Georgia]. In A. Borbíró, É. Inzelt, K. Kerezsi, M Lévay and L. Podoletz (eds.). A büntetöhatalom korlátainakmegtartása: a büntetés mint végsö eszköz (pp. 457-473). Budapest: ELTE Eötvös Kiadó.

Wikipedia (2010). Ajka alumina plant accident. https://en.wikipedia.org/wiki/Ajka_ alumina_plant_accident

Zimring, F. E. (1996). Populism, Democratic Government, and the Decline of Expert Authority: Some Reflections on Three Strikes in California. Pacific Law Journal, 28 (1), 243-256. 


\section{Sentences}

Budapest Környéki Törvényszék, (2013). Bkf. 1033/2013/3.

\section{Media sources}

Budapest Business Journal (2019). Court finds ten guilty in red sludge spill case. Budapest Business Journal. https://bbj.hu/news/court-finds-ten-guilty-in-red-sludge-spillcase_161023

Business Standard (2013). Judicial populism. Business Standard. http://www.businessstandard.com/article/opinion/judicial-populism-110122900016_1.html

Daily News Hungary (2014). Appellate court raises Rezesova prison sentence to 9 years. Daily News Hungary. https://dailynewshungary.com/appellate-court-raises-rezesovaprison-sentence-to-9-years/

Palfi and Tidey (2018). Homeless people face prison in Hungary after tough new law is passed. Euronews. https://www.euronews.com/2018/10/22/homeless-people-faceprison-in-hungary-after-tough-new-law-is-passed

Janecskó, Kata (2014). Súlyosbították Rezesova büntetését: kilenc év börtön. Index. https://index.hu/belfold/2014/09/11/rezesova_masodfok_itelet/

Kúria (2018). A megvádolt operatőr cselekménye nem valósította meg a garázdaság vétségét. Kúria. http://www.kuria-birosag.hu/hu/sajto/megvadolt-operator-cselekmenyenem-valositotta-meg-garazdasag-vetseget

Hungarian Spectrum (2013). Political interference with the Hungarian Judiciary. Hungarian Spectrum. https://hungarianspectrum.org/2013/12/05/political-interference-withthe-hungarian-judiciary/

Magyar Nemzet (2016). Bírósági ítéletekről vitázna a Fidesz. Magyar Nemzet. https://magyarnemzet.hu/archivum/belfold-archivum/birosagi-iteletekrol-vitaznaa-fidesz-3971958/

Mandinder (2016). Vörösiszap-per: az elsőfokú ítélet miatt tüntettek Veszprémben https://makronom.mandiner.hu/cikk/20160204_vorosiszap_per_az_elsofoku_ itelet_miatt_tuntettek_veszpremben

The Guardian (2009). The miscarriage of justice cases that came to light years later. https://www.theguardian.com/politics/2009/may/05/miscarriage-justice-innocentpeople-jailed

- (2018). Hungary passes anti-immigrant "Stop Soros" laws. The Guardian. https://www. theguardian.com/world/2018/jun/20/hungary-passes-anti-immigrant-stop-soroslaws

Youtube (2017). Az elsőfokú vörösiszap-ítélet értékelése (pódiumbeszélgetés) https://www. youtube.com/watch?v=3Juwye7FVo8 